CHORNY, H. Discriminated bar press avoidance. Journal of the Experimental Analysis of Behavior. 1961, 4, 309-316. KATZEV, R. Extinguishing avoidance responses as a function of delayed warning signal termination. Journal of Experimental Psychology, 1967, 75, 339-344.

LINDQUIST, E. F. Design and analysis of experiments in psychology and education. Boston: Houghton-Mifflin. 1953.
NAKAMURA, C. Y., \& ANDERSON, N. H. Avoidance behavior differences within and between strains of rats. Joumal of Comparative \& Physiological Psychology $1962,55,740-747$.

OLSON, R. D., DAVENPORT, D. G., \& K A M I CHOFF, N. C. Discriminated avoidance and the partial reinforcement effect. Psychonomic Science, 1971, 22. 12-14.

\title{
Conditional discrimination training and peak shifts in the pigeon*
}

\section{R. L. RUDOLPH, R. VAN HOUTEN, and J. MADDOX Dalhousie University, Halifax, N.S., Canada}

Pigeons were trained to make a conditional spectral discrimination with the presence and absence of a line serving as the conditional cue. In the presence of the line, responses to $540 \mathrm{~nm}$ were reinforced and responses to $530 \mathrm{~nm}$ were extinguished; in the absence of the line, responses to $530 \mathrm{~nm}$ were reinforced and responses to $540 \mathrm{~nm}$ were extinguished. The results of a spectral generalization test administered in both the presence and absence of the line were that all Ss exhibited conditional peak shifts.

Hanson (1959) demonstrated that the peak of the generalization gradient obtained after training pigeons on a successive spectral discrimination was not at the original positive training value but was displaced to the side of the positive stimulus, opposite the negative stimulus. An experiment by Boneau \& Honig (1963) contained conditions in which it was possible to obtain conditional peak shifts, although that was not the primary purpose of the experiment. They trained pigeons on a 550 vs $570 \mathrm{~nm}$ discrimination, with a vertical line and no line as the conditional cues. That is, in the presence of the line, $550 \mathrm{~nm}$ was positive and $570 \mathrm{~nm}$ was negative, whereas, in the absence of the line, $570 \mathrm{~nm}$ was positive and $550 \mathrm{~nm}$ was negative. The results of a generalization test on the spectral continuum given in the presence and absence of the line were that the peaks of the conditional gradients remained at the positive training values.

The purpose of the present experiment was to obtain conditional peak shifts. The major difference between our study and Boneau \& Honig's (1963) experiment was that we employed a $10-\mathrm{nm}$ spectral difference in training, whereas they employed a 20-nm difference. This procedural change was indicated by Hanson's (1959) result that moving $S-$ closer to $\mathrm{S}+$ on the spectral dimension produces larger peak shifts.

* This research was supported by Grant APA-297 from the National Research Council of Canada.

\section{SUBJECTS}

The Ss were five 6-month-old Silver King pigeons reduced to $80 \%$ of their ad lib weight.

\section{APPARATUS}

The apparatus consisted of a standard single-key pigeon chamber. The stimulus on the key was produced by interposing Bausch and Lomb interference filters, in conjunction with either a black vertical line or no line, between a $500 \cdot \mathrm{W}$ projector and the key. Light on the key provided the only illumination in the chamber, except for the magazine light which signaled 4-sec reinforcement.

PROCEDURE

Prediscrimination Training

On the first day, all Ss were shaped to peck the key, which was illuminated with 530 -nm line absent. Sixty 4-sec reinforcements were given, first on CRF and then on a VR 4 schedule. On the second day, the key was alternately illuminated with $530 \mathrm{~nm}$ line absent and $540 \mathrm{~nm}$ line present. These stimulus presentations lasted approximately $2 \mathrm{~min}$ and were separated by $10-\mathrm{sec}$ blackouts. Responses to both of these stimuli were reinforced on a gradually increasing VR schedule, which was shifted to a VI 30-sec schedule after the $\mathrm{S}$ was performing on a VR 20. Discrimination Training

Basically, the training procedure consisted of training the Ss to make a conditional discrimination with responses to a line reinforced in the presence of $540 \mathrm{~nm}$ and extinguished in the presence of $530 \mathrm{~nm}$, whereas responses to "no line" were reinforced in the presence of $530 \mathrm{~nm}$ and extinguished in the presence of
$540 \mathrm{~nm}$. Initially, each training day consisted of 32 2-min stimulus-on periods which were separated by $10 \mathrm{sec}$ of blackout. Each of the four stimulus conditions occurred eight times during a training session. The order of stimulus presentations was random, with the restrictions that the same stimulus could not be presented twice in a row and that each stimulus must occur twice in each block of eight trials. Reinforcement for correct responses was initially programmed on a VI 30-sec schedule. On the third day of discrimination training, a $3-\mathrm{sec}$ changeover delay was introduced for the termination of negative periods such that the 10-sec blackout would not start until 3 sec of no responding had occurred. This changeover delay was increased to $5 \mathrm{sec}$ on the fourth day of discrimination training and remained in effect for the remainder of training. When the color discriminations were better than $85 \%$ in both the presence and absence of the line, the number of stimulus-on periods was increased to 64, their duration was reduced to $1 \mathrm{~min}$, and the reinforcement schedule was changed to VI $1 \mathrm{~min}$. When the $85 \%$ criterion in both discriminations was met under these conditions, the number of stimulus-on periods was increased to 128 and their duration was decreased to $30 \mathrm{sec}$. Both of the increases in the number of stimulus-on periods were accomplished by simply recycling through the original order of 32 periods. On the day after the $\mathrm{S}$ reached the $85 \%$ criterion in both discriminations under the terminal training procedure, a generalization test was given. One $S$ was discarded because it failed even to approximate criterion after 25 days of training.

\section{Generalization Testing}

The generalization test stimuli consisted of six spectral values, 510 , $520,530,540,550$, and $560 \mathrm{~nm}$, each of which was paired with both the presence of the line and its absence. These 12 values were not presented in the typical randomized block manner. Instead, four blocks of the six spectral values were first presented either with or without the line. Then four more blocks were presented with the line condition reversed. This procedure of alternating the presence and the absence of the line every four blocks continued until the $\mathrm{S}$ had been given 16 blocks of stimulus presentations. S 4 was given an additional four blocks of testing in the no-line condition, since the position of the peak of the no-line spectral gradient was not clear. On the first set of four blocks, two of the Ss were presented with line-present stimuli; the other two Ss were presented with line-absent stimuli. During testing, stimulus-on periods 


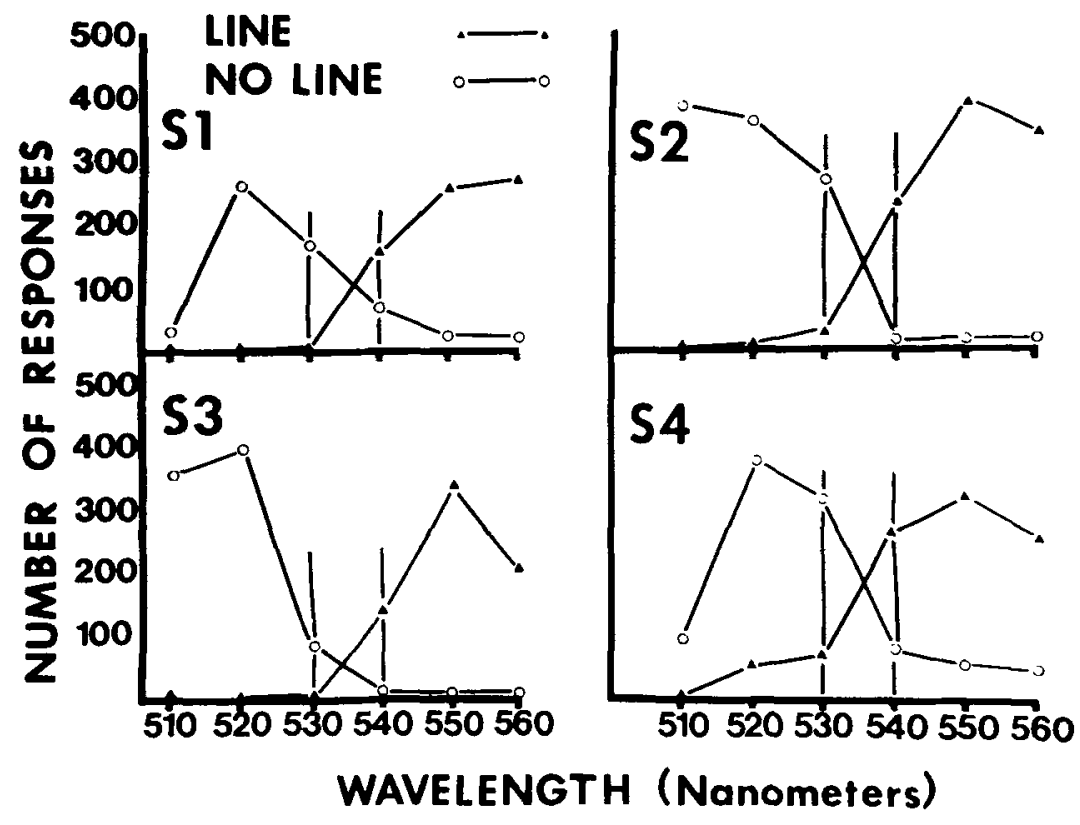

Fig. 1. Number of responses given to each of the spectral values in the line and no-line condition by each of the Ss. lasted for $30 \mathrm{sec}$ and were separated by 10 sec of blackout. Reinforcement was not available during testing.

RESULTS AND DISCUSSION

The number of days required to reach the final criterion ranged from 8 to 18 days, with a mean of 14 days. Hue discriminations in the presence and absence of the line were equally difficult: The mean percentage correct responses on the final day of training was $90 \%$ in both the line and no-line conditions. Two of the Ss performed

somewhat better on the hue discrimination in the line condition; the other two were somewhat better in the no-line condition. (Of the two Ss that were better in the line condition, one received test blocks of line stimuli first, while the other received blocks of no-line stimuli first. A similar assignment was made with the $S s$ which were better on the no-line discrimination.)

The number of responses that each $\mathrm{S}$ made to each of the 12 test stimuli is

Table 1

Percentage of Responses to Spectral Vatues With and Without Lines Over Blocks of Test Trials

\begin{tabular}{|c|c|c|c|c|c|c|c|c|}
\hline $\begin{array}{c}S \\
\text { Number }\end{array}$ & $\begin{array}{c}\text { Order } \\
\text { of Line } \\
\text { No-Line }\end{array}$ & $\mathbf{5 1 0}$ & 520 & 530 & 540 & 550 & 560 & $\begin{array}{c}\text { Number } \\
\text { of } \\
\text { Rs }\end{array}$ \\
\hline \multicolumn{9}{|c|}{ Spectral Values With Lines } \\
\hline 1 & $\begin{array}{l}(1) \\
(3)\end{array}$ & $\begin{array}{l}0.0 \\
0.0\end{array}$ & $\begin{array}{l}0.0 \\
0.5\end{array}$ & $\begin{array}{l}0.9 \\
0.9\end{array}$ & $\begin{array}{l}20.6 \\
23.7\end{array}$ & $\begin{array}{l}42.3 \\
26.0\end{array}$ & $\begin{array}{l}36.3 \\
48.9\end{array}$ & $\begin{array}{l}\mathbf{4 6 6} \\
219\end{array}$ \\
\hline 2 & $\begin{array}{l}\text { (1) } \\
\text { (3) }\end{array}$ & $\begin{array}{l}0.3 \\
0.0\end{array}$ & $\begin{array}{l}1.0 \\
0.3\end{array}$ & $\begin{array}{l}3.4 \\
0.3\end{array}$ & $\begin{array}{l}29.7 \\
13.7\end{array}$ & $\begin{array}{l}36.8 \\
43.8\end{array}$ & $\begin{array}{l}28.7 \\
41.9\end{array}$ & $\begin{array}{l}609 \\
372\end{array}$ \\
\hline 3 & $\begin{array}{l}(2) \\
(4)\end{array}$ & $\begin{array}{l}0.8 \\
0.0\end{array}$ & $\begin{array}{l}0.6 \\
0.0\end{array}$ & $\begin{array}{l}0.8 \\
0.5\end{array}$ & $\begin{array}{l}23.3 \\
11.6\end{array}$ & $\begin{array}{l}44.0 \\
61.1\end{array}$ & $\begin{array}{l}30.4 \\
26.9\end{array}$ & $\begin{array}{l}480 \\
216\end{array}$ \\
\hline 4 & $\begin{array}{l}\text { (2) } \\
\text { (4) }\end{array}$ & $\begin{array}{l}0.3 \\
0.0\end{array}$ & $\begin{array}{l}7.9 \\
0.0\end{array}$ & $\begin{array}{l}9.6 \\
3.3\end{array}$ & $\begin{array}{l}30.1 \\
23.2\end{array}$ & $\begin{array}{l}28.0 \\
43.5\end{array}$ & $\begin{array}{l}24.1 \\
30.1\end{array}$ & $\begin{array}{l}607 \\
336\end{array}$ \\
\hline \multicolumn{9}{|c|}{ Spectral Values Without Lines } \\
\hline 1 & $\begin{array}{l}(2) \\
(4)\end{array}$ & $\begin{array}{l}4.2 \\
4.6\end{array}$ & $\begin{array}{l}38.5 \\
65.5\end{array}$ & $\begin{array}{l}31.0 \\
28.7\end{array}$ & $\begin{array}{r}16.2 \\
1.1\end{array}$ & $\begin{array}{l}5.3 \\
0.0\end{array}$ & $\begin{array}{l}4.8 \\
0.0\end{array}$ & $\begin{array}{l}377 \\
174\end{array}$ \\
\hline 2 & $\begin{array}{l}(2) \\
(4)\end{array}$ & $\begin{array}{l}39.6 \\
33.6\end{array}$ & $\begin{array}{l}22.5 \\
50.8\end{array}$ & $\begin{array}{l}33.8 \\
14.4\end{array}$ & $\begin{array}{l}1.7 \\
0.0\end{array}$ & $\begin{array}{l}1.2 \\
0.7\end{array}$ & $\begin{array}{l}1.3 \\
0.5\end{array}$ & $\begin{array}{l}601 \\
431\end{array}$ \\
\hline 3 & $\begin{array}{l}\text { (1) } \\
\text { (3) }\end{array}$ & $\begin{array}{l}46.3 \\
34.4\end{array}$ & $\begin{array}{l}35.8 \\
63.2\end{array}$ & $\begin{array}{r}15.0 \\
0.9\end{array}$ & $\begin{array}{l}0.8 \\
1.5\end{array}$ & $\begin{array}{l}0.6 \\
0.0\end{array}$ & $\begin{array}{l}1.6 \\
0.0\end{array}$ & $\begin{array}{l}\mathbf{5 1 4} \\
\mathbf{3 3 7}\end{array}$ \\
\hline 4 & $\begin{array}{l}(1) \\
(3) \\
(5)\end{array}$ & $\begin{array}{r}13.3 \\
5.5 \\
0.0\end{array}$ & $\begin{array}{l}29.8 \\
43.0 \\
75.9\end{array}$ & $\begin{array}{l}30.2 \\
43.3 \\
19.8\end{array}$ & $\begin{array}{r}12.1 \\
4.5 \\
4.3\end{array}$ & $\begin{array}{l}7.7 \\
2.1 \\
0.0\end{array}$ & $\begin{array}{l}6.9 \\
1.7 \\
0.0\end{array}$ & $\begin{array}{l}547 \\
291 \\
116\end{array}$ \\
\hline
\end{tabular}

presented in Fig. 1. All Ss exhibited peak shifts in both the line and no-line test condition. In Table 1 , the number of responses made to each stimulus in each set of four blocks is expressed as a percentage of the total number of responses made in those blocks. The sum of the percentage of responses emitted to the peak shift stimuli ( 550 and $560 \mathrm{~nm}$ line present; 510 and $520 \mathrm{~nm}$ line absent) increased on the second set of four blocks under both the line and no-line conditions. Only $\mathrm{S} 1$ in the line condition failed to show this increase. It would be only partially correct, however, to characterize this increase in percentage of response given to the peak shift stimuli as an increase in the magnitude of the peak shift, since two Ss (Nos. 2 and 3 ) also exhibited shifts in the peaks of the gradients from 510 to $520 \mathrm{~nm}$ in the no-line condition.

The increase in percentage of responses emitted to the peak shift stimuli on the latter set of four blocks is primarily a function of a convergence of responding on the stimuli that are one step removed from

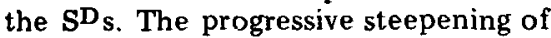
the gradient around the stimulus that is one step removed from $S D$ is similar to the steepening of the generalization gradient that Friedman \& Guttman (1965) observed with continued testing after spectral discrimination training.

The fact that conditional peak shifts were obtained in this experiment but were not obtained by Boneau \& Honig (1963) is presumably due to our use of a 10-nm spectral difference in training instead of a 20-nm difference. However, we used a testing procedure which differed from Boneau \& Honig's (1963) procedure, in that we presented blocks of line or no-line stimuli, whereas they employed a standard random block procedure in which line and no-line stimuli were intermingled during testing. Although it is possible that this difference in testing procedure may have contributed to the results, it seems more reasonable to assume that reduction of the spectral difference was the critical variable.

\section{REFERENCES}

BONEAU, C., \& HONIG, W. Opposed generalization gradients based upon conditional discrimination training. Joumal of Experimental Psychology, $1964,66,89-93$

FRIEDMAN, H., \& GUTTMAN, N. Further analysis of the various effects of discrimination training on stimulus generalization gradients. In D. Mostofsky (Ed.), Stimulus generalization. Stanford: Stanford University Press, 1965. Pp. 255-267.

HANSON, H, M. Effects of discrimination training on stimulus generalization. Joumal of Experimental Psychology, $1959,58,321-334$. 